\title{
Consumers' Expectation and Perception toward Mobile Telecommunication Usage in Bangladesh
}

\author{
Md. Ashraful Alam ${ }^{1 *}$, Debashish Roy², Rehana Akther ${ }^{3}$ \\ ${ }^{1}$ Lecturer, Department of Human Resource Management, University of Chittagong, BANGLADESH \\ ${ }^{2}$ Assistant professor, Department of Business Administration, Metropolitan University, BANGLADESH \\ ${ }^{3}$ Lecturer, Department of Business Administration, BGC Trust University, BANGLADESH \\ *E-mail for correspondence: ashraffalcon09@gmail.com
}

\begin{abstract}
Recently telecommunication sector like the mobile phone has made a revolution in the world. For the last few years, it has become part and parcel of our daily life. Business, commerce, and society cannot go out without the use of mobile phone. With the continuous diversification, the use of mobile is not only limited to talking, but its use ranges from using internet, sending messages, listening to music, to organizing various works are comfortably completed in time. City Cell Company introduced the use of mobile phone in Bangladesh in the middle of 1989 .Now with the lapse of time; another five operators have in the market. The mobile operators need to understand well, the perceptions of service quality of customers and their expectations. The study "Consumers' expectations and perception toward mobile telecommunication usage in Bangladesh" attempts to analyze the gap in telecom sector regarding customers' expectations and perceptions. It is important to investigate the differences which may provide scope for improvement of mobile service operators. Descriptive analysis, cross tabulation, Chi-square, frequency distribution was used to test the collected data and hypotheses of the research study. The study concludes that, given the severe competition in the business arena where mobile operators have to stay alive and breed by pricing strategy, network facilities, and promotional activities. Telecom companies will have to focus on the reduction of the gap in customer expectations and perceptions about their service quality if they are to race internationally. Hence, mobile operators should continually assess and reassess how customers perceive their services and to implement appropriate corrective action for retaining the existing customers and getting new customers.
\end{abstract}

Keywords: Mobile telecommunication, Consumers' Perception, Consumers' expectation, price, promotion

\section{INTRODUCTION}

Bangladesh is one of the poorest, most densely populated, least developed countries in the world. Apart from its lowly economic status, major impediments to growth have included frequent cyclones and floods and the slow implementation of much-needed economic reforms. The country also has a reputation for the inefficiency of its state-owned enterprises. Growth of the mobile internet customer base is expected to continue into 2016 and 2017. Present scenario of mobile phone subscribers in Bangladesh is like follow:

The total number of Mobile Phone Subscribers is as follow at the end of January, 2016

The Mobile Phone subscribers are listed below:

\begin{tabular}{|l|c|}
\hline Operator & $\begin{array}{c}\text { Subscriber } \\
\text { (in Millions) }\end{array}$ \\
\hline Grameen Phone Ltd. (GP) & 56.204 \\
\hline Banglalink Digital Communications Limited & 32.368 \\
\hline Robi Axiata Limited (Robi) & 27.795 \\
\hline Airtel Bangladesh Limited (Airtel) & 10.510 \\
\hline Pacific Bangladesh Telecom Limited (Citycell) & 0.867 \\
\hline Teletalk Bangladesh Ltd. (Teletalk) & 4.211 \\
\hline Total & $\mathbf{1 3 1 . 9 5 6}$ \\
\hline
\end{tabular}

Source: www.btrc.gov.bd

* Subscribers in Million

**The above subscribers' numbers are declared by the mobile operators

For the month of January, 2016

Customer perception defines the way that customer usually view or feed about certain services and products. It relates to customer satisfaction which is the expectation of the customer towards the product/service. Telecommunication services providers are of paramount importance to both developed and emerging economic in the world. With stiff competition between the mobile operators, customer satisfaction is a necessity for survival in the market. Many telecommunication services providers are offering various products and services in the market. Customer perception is a personal feeling of either pleasure or disappointment resulting from the evaluation of service provided by an organization to an individual about expectations.

Meeting and exceeding expectations of clients and customers that means delighting, is a viewpoint that has gained most attraction. This concept is all inclusive and cuts across service domains, but expectations change and 
experiences with alternate service providers could shape the customers' expectations. The research gap here is attaining customers' expectation towards a particular service. A gap is a difference, imbalance or disparity which is determined to exist between customers' perception of firm performance and their prior expectation.

Rahman Sabbir, Haque Ahasanul, Ahmad Mohd Ismail Sayyed (2011), in their study "Choice Criteria for Mobile Telecom Operator: Empirical Investigation among Malaysian Customers" investigated the choice criteria for a mobile phone operator in the Malaysian Mobile Telecom market by the customers. The outcome of this research shows a comprehensively integrated framework in which to understand the close relationships among several dimensions of service quality, price, and brand image to have a handful idea on the consumers' perceptions.

Rahman Dr. Muhammad Sabbir, (2012), in his study "Service quality, corporate image and customers' satisfaction towards customers perception: An exploratory study of telecom customers in Bangladesh" aimed at the determinants that are significantly influencing telecom customers' in Bangladesh. The study revealed that most of the telecom customers are highly concerned about service quality followed by corporate image

\section{OBJectives OF THE StUdy}

The prime purpose of the research is to identify consumers' expectation and perception from mobile phone companies in Bangladesh. To emerge the objective some other supporting objectives are:

- To investigate the nature influencers in the selection of mobile operators.

- To appraise the impact of promotional offers.

- To justify the impact of network facility on consumers' expectation.

- To see a relation between satisfaction on network availability and connection type.

\section{LITERATURE REVIEW}

Leisen B, Vance C,(2001), in their research paper "Customer satisfaction, Globalization, International Trade, Service Quality, Strategy, Telecommunication Industry" examined the strategic implications of service quality dimensions about customer satisfaction in a cross- cultural study of telecommunication service provision in Germany and the USA. Significant differences found between the two countries regarding the relative importance of particular service dimensions.

According to Leisen and Vance (2001), service quality helps to create the necessary competitive advantage by being an effective differentiating factor. Service quality was initiated in the 1980s as the worldwide trend when marketers realized that only a quality product could not be guaranteed to maintain competitive advantage (Wal et al., 2002). However, competitive advantage by firms is a valuecreating strategy; simultaneously potential competitors were not able to implement it (Barney, 1991). As a result, service quality can be used as a competitive advantage which is related to customers' satisfaction and also leads to consumer loyalty and future purchase (Johnson and Sirikit, 2002).

In particular customers prefer service quality when the price and other cost elements are held constant (Boyer and Hult, 2005). It has become a distinct and significant aspect of the product and service offering (Wal et al., 2002). Moreover, according to them, a competitive advantage also sustained when other companies are unable to duplicate the benefits of this strategy. Service quality is essential for a telecommunication service provider company to ensure the quality service for establishing and maintaining loyal and profitable customer (Zeithaml, 2000; Leisen and Vance, 2001). Conversely, Johnson and Sirikit (2002) state as service delivery systems has the ability to allow managers of the company to identify the real customer feedback and satisfaction on their telecommunication service. Quality reflects the customers' expectations about a product or service. Lovelock (1996) stated that this customer driven quality replaced the traditional marketing philosophies which were based on products and process. Service quality is different from the quality of goods. Since, services are intangible, perishable, produced and consumed simultaneously and heterogeneously (Zeithaml and Bitner, 2000).

Lehtinen \& Lehtinen (1991) suggest that quality cultivates during two-way interaction between service providers and customers. According to them, there are three dimensions: physical quality includes the tangible aspect of the service; the corporate quality which involves the company's image and interactive quality which originates from an interaction between customer and service provider. (Lehtinen \& Lehtinen 1991) Has observed that service quality has two dimensions - process and output. Process quality emphasizes in the way service is catered to a consumer and output quality is judged once service is provided. Evaluation of service process plays a vital role in building the perception of consumers. Process quality is evaluated while the service is being provided and the outcome is evaluated once it is provided.

Perceived quality is a kind of attitude that results from a comparison of expected service with perceived service. It is a consumer's verdict developed about the superior performance of the service (Gi-Du Kang, 2006). Expected service originates from the word of mouth communication, personal needs, and past experiences. Expected services are the desires, wants of a consumer i.e. what they feel that service should offer rather than would offer. A perceived service is the outcome of external communication to consumer and service delivery process. According to Parasuraman et al. (1985), service quality depends on the incongruity between expected services and perceived services.

Price plays a vital role in telecommunication market especially for the mobile telecommunication service providers (Kollmann, 2000). It includes not only the buying price but also the call and rental charges. A price-dominated mass market leads to customers having more choices and 
opportunities to compare the pricing structures of diverse service providers. A company that offers lower charges would be able to attract more customers committing themselves to the telephone networks, and hence, a significant number of "call minutes" might be achieved. According to Kollmann (2000), income from the number of call minutes determines the commercial success for the network providers. He also added that the success of the telecommunication sector in a market largely depends on continuing usage and pricing policies, which need to be considered on several levels. Draganska and Jain (2003) stated that a strategy for a company extending their product or service is to differentiate their offerings vertically. In this era of information age, price competition has become cutthroat in the mobile telecommunication industry. Trebing (2001) mentioned that there are three sets of strategies for pricing behavior. The first is entry limit pricing, which is used for protection of the market position of the firm; a second is the high access charges for new entrants, and the third one is tiein sales to write off the old plant or standard investment against captive customers. According to the author, entry limit pricing involves setting low prices in highly flexible markets to attract or retain large customers with monopolistic buying power, while maintaining high prices in inelastic markets. Consumer research over the past three decades has documented the persistent impact that price has on consumer perceptions of a product (Janakiraman et al., 2006; Vanhuele et al., 2006). Customers in telecommunication industry have preconceived notions about the price and value of telecommunications services. Customers have historically complained about the level of local charges, more than they have about long distance; although, local service is frequently offered at a price lower than actual cost. When long-distance service is priced well over cost, and local service is priced well under cost, customers expect to pay very low prices for local services and apparently do not mind that long distance could be less expensive but is not (Strouse, 1999)

Consumer's perception of product quality is always an important aspect of a purchasing decision and market behavior. Consumers regularly face the task of estimating product quality under conditions of imperfect knowledge about the underlying attributes of the various product offers with the aid of personal, self-perceived quality criteria (Bedeian, 1971 adapted by Sjolander, 1992). According to Sjolander (1992), the consumer behavior in the modern market is different from the theoretical case of consumer decision making in free markets. Generally, free and competitive markets are composed of buyers and sellers each of whom must possess perfect information about all possible products and their respective utilities; a well defined and explicit set of performances; the ability to determine optimal combination of various products given their budget constraints; a knowledge of prices, which does not affect the subjective wants or satisfaction of the consumer (Monroe and Petroshius, 1973 adapted by Sjolander, 1992). It is necessary to define quality in the first place before it can be measured. There is no global definition of quality exists (Sebastianelli and Tamimi, 2002), it can be defined in varieties of ways. Yoon and Kijewski (1997) pointed out that quality can be categorized into two perspectives. One is the marketer's perspective, which is product-based or manufacturing-based and the other one is consumer's perspective, which is user-based or value-based. Product quality from the marketer's perspective is associated with feature, function or performance of a product. On the other hand, product quality from the consumer's perspective is associated with the capacity of a product to satisfy consumer needs (Archibald et al., 1983). According to Lambert (1980), consumers often attribute the quality to branded products on the basis of price, brand reputation, store image, market share, product features and country of manufacture. So, price is an indicator to measure the product quality, which is based on the theory that quality is a measure of the utility, or the want-satisfying capacity of products (Sjolander, 1992). The author has also added that the more the quality a product possesses, the more the utility it contains, and the higher the price it will obtain in an open market exchange. This means that similar products offered to the market at different prices, contain different amounts of utility, and that there is a direct relationship between quality and price. The actual pricequality relationship is a complex interaction between price, brand name, store image, product features, and brand awareness (Lambert, 1980; Gerstner, 1985). Oliver (1993) identified a few major elements that differentiate between service quality and satisfaction. It was suggested that, the dimensions that comprise quality judgments are quite specific to the service delivered. As for satisfaction, it can be determined by a broader set of factors including those which are outside the immediate service delivery experience (e.g. a mobile phone subscribers satisfaction depend on his/her mobile phone operators may be influenced by whether his/her need; mood on that particular day when that consumer want to purchase a line). Ting (2004) indicated that perceptions of service quality do not depend on experiences with the service environment or service providers, while judgments of satisfaction depend on past experiences. He also mentioned that quality is believed to be determined more by external cues (e.g. price, reputation) whereas satisfaction is more driven by conceptual cues (e.g. equity, regret).

\section{Methodology OF THE STUdY}

Population and sampling design: The data were collected from different areas of Dhaka, Sylhet, Rajshahi, and Chittagong divisions from December, 2015 to February, 2016. The sample size was 150 and sampling method adopted was a combination of Judgmental and Simple Random Sampling. 
Sample characteristics: The respondents were chosen irrespective of gender, age, income, education, occupation, religion, location. All the interviewed respondents were the subscriber of different mobile phone operators.

Instrumentation: The instrument used for data collection was a questionnaire developed to assess consumers' expectation and perception toward telecommunication usage. To measure the responses of the respondents a five- point scale of strongly agree (5), Agree (4), Neutral (3), Disagree (2) Strongly disagree (1) were used.

Data analysis: Cross tabulation, Chi-square, and frequency distribution were used for analyzing the data. For, sharp outcome of those analyses, Statistical software, SPSS was used.

Reliability: Cronbach's alpha is a measure of internal consistency, that is, how closely related a set of items are as a group. It is considered to be a measure of scale reliability. In this study, the alpha value was found 0.739 which is a good indicator.

\section{Hypotheses OF THE STUdY}

$\mathrm{H}_{1}$ : There is no relationship between gender of the respondents and influencer in mobile operator selection

$\mathrm{H}_{2}$ : There is no relation between factors affects mobile phone subscription and gender of the respondents

$\mathrm{H}_{3}$ : There is no relationship between connection type and price based satisfaction

$\mathrm{H}_{4}$ : There is no relation between internet related service satisfaction and connection type

$\mathrm{H}_{5}$ : There is no relation between satisfaction on network facility and connection type

$\mathrm{H}_{6}$ : There is no significant relationship between connection type and promotional offers based satisfaction

\section{Data ANALYsis AND SURVEy Findings}

Table 1: Demographic information of the respondents

\begin{tabular}{|c|c|c|c|c|c|}
\hline \multirow{4}{*}{ Gender } & & Frequency & Percent & Valid Percent & Cumulative Percent \\
\hline & male & 106 & 70.7 & 70.7 & 70.7 \\
\hline & female & 44 & 29.3 & 29.3 & 100.0 \\
\hline & Total & 150 & 100.0 & 100.0 & \\
\hline \multirow[t]{6}{*}{ Age } & $15-20$ years & 19 & 12.7 & 12.7 & 12.7 \\
\hline & 21-25 years & 98 & 65.3 & 65.3 & 78.0 \\
\hline & $26-30$ & 19 & 12.7 & 12.7 & 90.7 \\
\hline & $30-35$ & 9 & 6.0 & 6.0 & 96.7 \\
\hline & $36-40$ & 5 & 3.3 & 3.3 & 100.0 \\
\hline & Total & 150 & 100.0 & 100.0 & \\
\hline \multirow[t]{7}{*}{ Monthly family income } & less than tk. 10,000 & 15 & 10.0 & 10.0 & 10.0 \\
\hline & Above tk. 10,000-20,000 & 21 & 14.0 & 14.0 & 24.0 \\
\hline & above tk. 20,000-30,000 & 41 & 27.3 & 27.3 & 51.3 \\
\hline & above tk. $30,000-40,000$ & 26 & 17.3 & 17.3 & 68.7 \\
\hline & above tk. 40,000-50000 & 18 & 12.0 & 12.0 & 80.7 \\
\hline & above tk. 50,000 & 29 & 19.3 & 19.3 & 100.0 \\
\hline & Total & 150 & 100.0 & 100.0 & \\
\hline \multirow[t]{3}{*}{ Marital status } & single & 117 & 78.0 & 78.0 & 78.0 \\
\hline & married & 33 & 22.0 & 22.0 & 100.0 \\
\hline & Total & 150 & 100.0 & 100.0 & \\
\hline \multirow[t]{7}{*}{ Educational level } & primary & 5 & 3.3 & 3.3 & 3.3 \\
\hline & secondary & 3 & 2.0 & 2.0 & 5.3 \\
\hline & higher secondary & 32 & 21.3 & 21.3 & 26.7 \\
\hline & graduate & 94 & 62.7 & 62.7 & 89.3 \\
\hline & post graduate & 15 & 10.0 & 10.0 & 99.3 \\
\hline & others & 1 & .7 & .7 & 100.0 \\
\hline & Total & 150 & 100.0 & 100.0 & \\
\hline \multirow[t]{6}{*}{ Occupation } & business & 26 & 17.3 & 17.3 & 17.3 \\
\hline & service & 15 & 10.0 & 10.0 & 27.3 \\
\hline & student & 103 & 68.7 & 68.7 & 96.0 \\
\hline & house wife & 4 & 2.7 & 2.7 & 98.7 \\
\hline & others & 2 & 1.3 & 1.3 & 100.0 \\
\hline & Total & 150 & 100.0 & 100.0 & \\
\hline
\end{tabular}


Table 2: Satisfaction level of the respondents

\begin{tabular}{|c|c|c|c|c|c|c|c|}
\hline \multirow[t]{2}{*}{ Satisfaction level } & \multirow[t]{2}{*}{ means } & \multirow{2}{*}{$\begin{array}{c}\text { Std. } \\
\text { Deviation }\end{array}$} & \multicolumn{5}{|c|}{ Percentage of response } \\
\hline & & & $\begin{array}{c}\text { Highly } \\
\text { dissatisfied }\end{array}$ & Dissatisfied & Neutral & Satisfied & $\begin{array}{c}\text { Highly } \\
\text { satisfied }\end{array}$ \\
\hline $\begin{array}{l}\text { By price (SIM price, call/ } \\
\text { video call charges, etc.) }\end{array}$ & 3.2133 & .87919 & $\begin{array}{c}8 \\
5.3 \% \\
\end{array}$ & $\begin{array}{c}18 \\
12 \%\end{array}$ & $\begin{array}{c}61 \\
40.7 \%\end{array}$ & $\begin{array}{c}60 \\
40 \%\end{array}$ & $\begin{array}{c}3 \\
2 \% \\
\end{array}$ \\
\hline $\begin{array}{l}\text { By internet packages, } \\
\text { charges and services }\end{array}$ & 2.9800 & .99306 & $\begin{array}{c}15 \\
10 \% \\
\end{array}$ & $\begin{array}{c}27 \\
18 \% \\
\end{array}$ & $\begin{array}{c}57 \\
38 \% \\
\end{array}$ & $\begin{array}{c}48 \\
32 \% \\
\end{array}$ & $\begin{array}{c}3 \\
2 \% \\
\end{array}$ \\
\hline By network facilities & 3.3733 & .76454 & $\begin{array}{c}3 \\
2 \%\end{array}$ & $\begin{array}{c}13 \\
8.7 \%\end{array}$ & $\begin{array}{c}63 \\
42 \%\end{array}$ & $\begin{array}{c}67 \\
44.7 \%\end{array}$ & $\begin{array}{c}4 \\
2.7 \%\end{array}$ \\
\hline By customer care service & 3.3267 & .77283 & $\begin{array}{c}1 \\
0.7 \%\end{array}$ & $\begin{array}{c}19 \\
12.7 \%\end{array}$ & $\begin{array}{c}66 \\
44 \%\end{array}$ & $\begin{array}{c}58 \\
38.5 \%\end{array}$ & $\begin{array}{c}6 \\
4 \%\end{array}$ \\
\hline By various promotional offers & 3.3067 & .80223 & $\begin{array}{c}5 \\
3.3 \%\end{array}$ & $\begin{array}{c}13 \\
8.7 \%\end{array}$ & $\begin{array}{c}67 \\
44.7 \% \\
\end{array}$ & $\begin{array}{c}61 \\
40.7 \%\end{array}$ & $\begin{array}{c}4 \\
2.7 \%\end{array}$ \\
\hline
\end{tabular}

Table-2 shows the satisfaction levels of respondents on the basis of different criteria. It is found that satisfaction level on the basis of price is almost moderate (mean value 3.2133). The amount of highly dissatisfied or highly satisfied is not noteworthy. $40 \%$ respondents implied that they were satisfied with the SIM price, voice and video call charges where as $40.7 \%$ respondents took a neutral position.

The internet is now the part and parcel of mobile phone subscription. While examining the satisfaction level of respondents for internet packages, charges, and service, the mean value of the responses was found 2.9800 which indicate that respondents are merely dissatisfied in regarding of internet service provided by the operators.

The reasons for that were identified by researchers through focus group discussion with respondents. The prominent reason are- unclear promotional messages, high price, and slow network speed.
Respondents' satisfaction level is relatively high in case of network facilities. $42 \%$ provided neutral response where $44.7 \%$ respondents stated that they are satisfied with current network facilities. Focus group discussions revealed that increased competition among the service providers is the dominant factor for improved network facility.

Respondents' customer care service experience is also pleasing. Though $44 \%$ took a neutral position, $38.5 \%$ were satisfied, and $4 \%$ were highly satisfied with customer care services. Only $12.7 \%$ of the respondents were dissatisfied with customer care service. A negligible $0.7 \%$ was highly dissatisfied.

All mobile operators provide different promotional offers to attract and retain their customers. It is found in the study that a significant number of respondents were satisfied with those promotional offers. Focus group discussion with respondents identified that due to severe competition most of the operators give different innovative and attractive promotional offers.

Table 3: influencer in mobile operator Selection

\begin{tabular}{|c|c|c|c|c|c|c|c|c|}
\hline & \multicolumn{5}{|c|}{ Factors influenced you in choosing mobile phone operator } & \multirow[t]{2}{*}{ Total } & \multirow[t]{2}{*}{ Chi-Square } \\
\hline & & $\begin{array}{c}\text { Family } \\
\text { members }\end{array}$ & friends & relatives & Advertisement & $\begin{array}{l}\text { dealers / } \\
\text { retailers }\end{array}$ & & \\
\hline \multirow[t]{4}{*}{ Gender } & Male & 29 & 55 & 10 & 7 & 5 & 106 & \multirow{6}{*}{$\begin{array}{c}\text { Value-13.870 } \\
(\text { Sig } 0.008)\end{array}$} \\
\hline & & $27.4 \%$ & $51.9 \%$ & $9.4 \%$ & $6.6 \%$ & $4.7 \%$ & $100.0 \%$ & \\
\hline & Female & 24 & 17 & 0 & 3 & 0 & 44 & \\
\hline & & $54.5 \%$ & $38.6 \%$ & $.0 \%$ & $6.8 \%$ & $.0 \%$ & $100.0 \%$ & \\
\hline \multirow{2}{*}{\multicolumn{2}{|c|}{ Total }} & 53 & 72 & 10 & 10 & 5 & 150 & \\
\hline & & $35.3 \%$ & $48.0 \%$ & $6.7 \%$ & $6.7 \%$ & $3.3 \%$ & $100.0 \%$ & \\
\hline
\end{tabular}

\section{S=significant}

Table 3 shows the influence of respondents' mobile operator selection. It is found in the study that females $(54.5 \%)$ are more influence by family members than male $(27.4 \%)$ respondents. Male respondents are mainly influenced by their friends $(51.9 \%$ of the total male respondents). The overall influences of dealers/retailers are little (only 3.3\%). Since P-value is found 0.008 at 5\% level of significance researchers reject the $\mathrm{H} 01$ and came to a conclusion that there is a relationship between gender of the respondents and influencer in mobile operator selection. 
Table 4: Factors considered in deciding mobile phone subscription

\begin{tabular}{|c|c|c|c|c|c|c|c|c|}
\hline & \multicolumn{5}{|c|}{$\begin{array}{l}\text { In deciding mobile phone subscription, } \\
\text { which factor do you consider? }\end{array}$} & Total & \multirow[t]{2}{*}{ Chi-Square } \\
\hline & & $\begin{array}{l}\text { Brand } \\
\text { image }\end{array}$ & $\begin{array}{l}\text { Price/ } \\
\text { charges }\end{array}$ & $\begin{array}{l}\text { Availability } \\
\text { (network) }\end{array}$ & $\begin{array}{c}\text { Customer care } \\
\text { service }\end{array}$ & $\begin{array}{l}\text { Offers and } \\
\text { features }\end{array}$ & & \\
\hline \multirow[t]{4}{*}{ Gender } & \multirow[t]{2}{*}{ Male } & 12 & 43 & 42 & 6 & 3 & 106 & \multirow{6}{*}{$\begin{array}{c}\text { Value-18.439 } \\
(\text { Sig } 0.001)\end{array}$} \\
\hline & & $11.3 \%$ & $40.6 \%$ & $39.6 \%$ & $5.7 \%$ & $2.8 \%$ & $100.0 \%$ & \\
\hline & \multirow[t]{2}{*}{ Female } & 3 & 24 & 5 & 6 & 6 & 44 & \\
\hline & & $6.8 \%$ & $54.5 \%$ & $11.4 \%$ & $13.6 \%$ & $13.6 \%$ & $100.0 \%$ & \\
\hline \multirow{2}{*}{\multicolumn{2}{|c|}{ Total }} & 15 & 67 & 47 & 12 & 9 & 150 & \\
\hline & & $10.0 \%$ & $44.7 \%$ & $31.3 \%$ & $8.0 \%$ & $6.0 \%$ & $100.0 \%$ & \\
\hline
\end{tabular}

S=significant

Customers consider various factors in deciding mobile phone subscription. Table- 4 shows that $44.7 \%$ of total respondents consider the price (call rate or SIM) for selecting their subscription. It is found in the study that female respondents more about customer care services and offers, features than male. However male respondents pay attention to network availability after price. The $\mathrm{p}$-value is found for Chi-square test is 0.001 at $5 \%$ level of significance that is why $\mathrm{H} 02$ is rejected. Researchers accepted the alternative hypothesis and concluded that gender of the respondent and mobile subscription factors are related.

Table 5: Price based satisfaction and Connection type (cross tabulation)

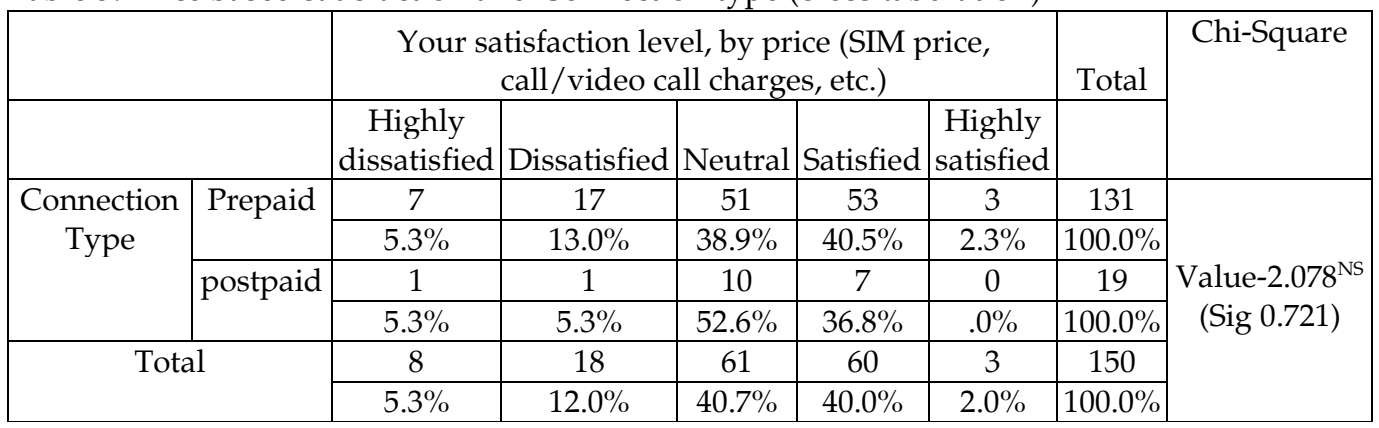

NS= not significant

It is found in the study that prepaid subscribers are more satisfied than post paid subscribers (Table 5). None of the post paid customers were found highly satisfied whereas a majority of the post paid customers took a neutral position (52.6\%). The H03 (there is no relationship between connection type and price based satisfaction) is accepted since p-value is found 0721 at $5 \%$ level of significance.

Table 6: Internet service satisfaction and connection type (cross tabulation)

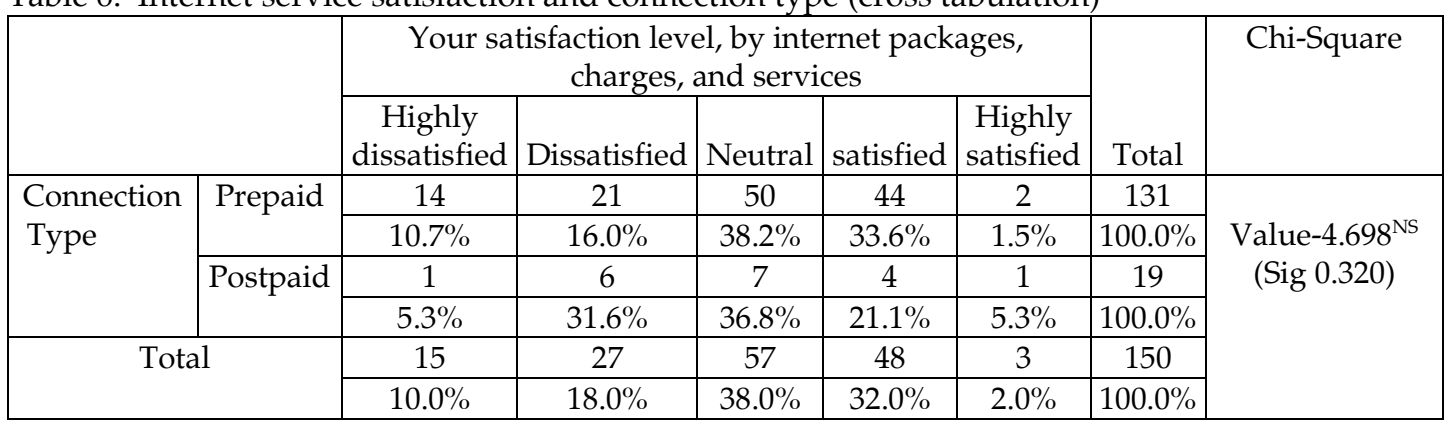

$\mathrm{NS}=$ not significant

Table 6 shows the cross-tabulation between internet service satisfaction and connection type. It is also found here that prepaid customers are more satisfied regarding internet facilities than the post paid customers. A significant portion of the postpaid customers (31.6\%) was found dissatisfied in the study. By performing Chisquare test, researchers accepted the H04 since the pvalue is found 0.320 and concluded that connection type and internet service satisfaction are not linked. 
Table 7: Satisfaction with network facilities and connection type (cross tabulation)

\begin{tabular}{|c|c|c|c|c|c|c|c|c|}
\hline & \multicolumn{5}{|c|}{ Satisfaction level by network facilities. } & \multirow[t]{2}{*}{ Total } & \multirow[t]{2}{*}{ Chi-Square } \\
\hline & & \begin{tabular}{c|} 
Highly \\
dissatisfied
\end{tabular} & Dissatisfied & Neutra & Satisfied & $\begin{array}{c}\text { Highly } \\
\text { satisfied }\end{array}$ & & \\
\hline \multirow{4}{*}{$\begin{array}{c}\text { Connection } \\
\text { Type }\end{array}$} & Prepaid & 3 & 12 & 52 & 60 & 4 & 131 & \multirow{6}{*}{$\begin{array}{c}\text { Value-2.913 } \\
\text { (Sig 0.573) }\end{array}$} \\
\hline & & $2.3 \%$ & $9.2 \%$ & $39.7 \%$ & $45.8 \%$ & $3.1 \%$ & $100.0 \%$ & \\
\hline & Postpaid & 0 & 1 & 11 & 7 & 0 & 19 & \\
\hline & & $.0 \%$ & $5.3 \%$ & $57.9 \%$ & $36.8 \%$ & $.0 \%$ & $100.0 \%$ & \\
\hline \multirow{2}{*}{\multicolumn{2}{|c|}{ Total }} & 3 & 13 & 63 & 67 & 4 & 150 & \\
\hline & & $2.0 \%$ & $8.7 \%$ & $42.0 \%$ & $44.7 \%$ & $2.7 \%$ & $100.0 \%$ & \\
\hline
\end{tabular}

NS= not significant

In examining satisfaction level of respondents regarding network facilities, it is found that majority of the respondents are satisfied with current network facilities (Table 7 ). Nearly $11 \%$ provided a negative approach toward network facilities. Since the p-value was found 0.573 researchers accept the $\mathrm{H} 05$ at $5 \%$ level of significance and conclude that there is no relation between satisfaction on network facility and connection type.

Table 8: Promotional offers and connection type (cross tabulation)

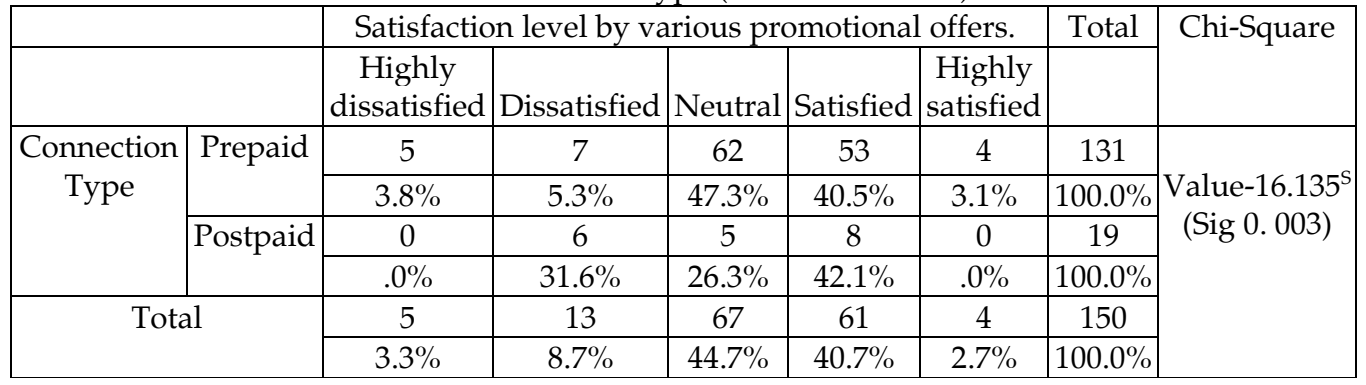

S=significant

Table 7 shows the respondents' satisfaction regarding various promotional offers provided by the operators. In the case of prepaid connection, subscribers provided almost positive attitude (47.3\% were neutral, and $40.5 \%$ were satisfied). It is found in the study that a number of dissatisfied customers is more in post paid connection than prepaid. The null hypothesis (H06) is, there is no significant relationship between connection type and promotional offers based satisfaction. Since the $p$-value is found, 0.003 researchers reject the null hypothesis at 5\% level of significance.

\section{CONCLUSION}

This study was undertaken to examine and understand the consumers' expectation and perception toward telecommunication usage in Bangladesh. Researchers have found that there is relationship between gender of the respondents and influencer in mobile operator selection, gender of the respondent and mobile subscription factors are related, there is no relationship between connection type and price based satisfaction, connection type and internet service satisfaction are not linked, there is no relation between satisfaction on network facility and connection type. There is no significant relationship between connection type and promotional offers based satisfaction. The operators should also focus on the smooth flow of network coverage, customer care services, and the speed of internet services as well as corporate social responsibilities. They should be aware about the abuses of the mobile phone. The operators themselves may generate new ideas, initiatives by which they can delight the customers.

\section{REFERENCES}

Archibald RB, Haulman CA, Moody CE Jr (1983). "Quality, price, advertising, and published quality ratings," J. Consum. Res., 9(3): 347-56.

Barny JB (1991). “Firm Resources and Sustained Competitive Advantage", J. Manage. 17(3): 99-120.

Bedeian AG (1971). "Consumer Perception of Price as an Indicator of Product Quality," MSU Business Topics, Summer, pp. 59-65,

Boyer KK, Hult GT (2005). "Customer Behavior in an Online Ordering Application: A Decision Scoring Model", Dec. Sci., 36(4): 569-598.

Cato Iacob, Garden Daniel Adrian, (2010) "Romania Consumer perception towards mobile marketing campaigns, " Annales Universitatis Apulensis Series Oeconomica, 12(2),

Draganska M, Jain DC (2003). "Consumer Preferences and Product line Pricing Strategies: An Empirical Analysis", Conference Paper, Marketing Science Conference, Maryland, Available at: / http:/ / facultygsb.stanford.edu/draganska/PDF_Files/1li nelength_FL61.pdf,

Gerstner E (1985). "Do higher prices signal higher quality?" J. Mark.Res., 22(5): 209-15.

Janakiraman N, Meyer RJ, Morales AC (2006). “Spillover effects: how consumers respond to unexpected changes in prices and quality," J.Consum. Res., 33(3): 361-72. 
Johnson WC, Sirikit A (2002). "Service Quality in the Thai Telecommunication Industry: A Tool for Achieving a Sustainable Competitive Advantage," Manage. Dec. 40(7): 693-701.

Kang, Gi-Du. (2006). The Hierarchical Structure of Service Quality: Integration of Technical and Functional Quality. Managing Service Quality, 16(1), 37-50.

Kollmann T (2000). "The Price/Acceptance Function: Perspectives of a Pricing Policy in European Telecommunication Markets," Eur. J.Innov. Manage. 3(1): 7-14.

Lambert DR (1980). "Price as a quality signal: the tip of the iceberg," Econ. Inq., 18(1): 144-50

Lehtinen, J.R., \& Lehtinen, U. (1991). Two approaches to service quality dimensions. The Service Industries Journal, 11(3), 287-303

Leisen B, Vance C (2001). "Cross-national Assessment of Service Quality in the Telecommunication Industry: Evidence from the USA and Germany," Manag. Ser. Qual., 11(5); 307-317

Lovelock CH (1996). Services Marketing, 3rd Edition, PrenticeHall, Upper Saddle River, NJ. pp. 47-82.

Parasuraman, A., Zeithaml, Valarie .A., \& Berry, Leonard. L. (1985). A Conceptual Model of Service Quality and its Implication for Future Research. Journal of Marketing, 49, 41-50

Rahman Dr.Muhammad Sabbir(2012) " Service quality, corporate image, and customer's satisfaction towards customer perception: An exploratory study of telecom customers in Bangladesh."

Rahman Sabbir, Haque Ahasanul, Ahmad Mohd Ismail Sayyed (2011) "Choice Criteria for Mobile Telecom Operator:
Empirical Investigation among Malaysian Customers" International Management Review Vol. 7 No. 1

Sjolander R (1992), “Cross-cultural Effects of Price on Perceived Product Quality", Eur. J. Mark. 26(7): 34-44.

Ting DH (2004). "Service quality and satisfaction perceptions: curvilinear and interaction effect," Int. J. Bank Mark., 22(6): 407-420.

Trebing HM (2001). "Emerging Market Structures and Options for Regulatory Reform in Public Utility Industries," Telecom Reform: Principles, Policies and Regulatory Practices, Editor William H.Melody, Reprint 2001, Schultz DocuCenter, Denmark.

Vanhuele M, Laurent G, Dreze X (2006). “Consumers' immediate memory for prices," J. Consum. Res., 33(2): 16374.

Wal RWE, Van der PA, Bond C (2002). "Service Quality in a Cellular Telecommunications Company: A South African Experience", Managing Serv. Q., 12(5): 323-335.

Yoon E, Kijewski V (1997). "Dynamics of the Relationship between Product Features, Quality Evaluation, and Pricing," Pricing Strat. Pract., 5(2): 45-60.

Zeithaml VA (2000). "Service Quality, Probability and the Economic Worth of Customers: What We Know, and What We Need to Learn," J. Acad. Mark. Sci. 28(1): 67-85.

Zeithaml VA, Bitner MJ (2000). Services Marketing: Integrating Customer Focus Across the Firm, 2nd Edition, McGraw Hill, New York, NY.

\section{Publish Online and Print Version Both}

Online ISSN: $2305-8730$

Online Archive: $\underline{\text { http://journals.abc.us.org/index.php/abr/issue/archive }}$

Indexed Archive Links

OCLC WorldCat: $\underline{\text { http://goo.gl/vhQzla }}$

Google Scholar: https://goo.gl/t23FeQ

abcGATE: http://goo.gl/E6WdgA

BASE: $\underline{\text { http://goo.gl/sEd0SZ }}$

\section{5) Worldcat Google scholar

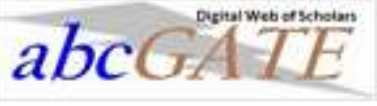

